\title{
Families of Children with Cancer Regarding Support Sources and Coping Strategies
}

\author{
Feyruz Usluoğlu, Toros University, ORCID ID: 0000-0002-3012-1386 \\ Meral Atıcı, Çukurova University, ORCID ID: 0000-0003-0675-4439
}

\begin{abstract}
The purpose of this study is to investigate views of parents and siblings of children with cancer whose treatment is continuing about family support sources and individual coping strategies. In line with this purpose, face to face interviews were conducted with 24 parents and 12 siblings from 12 families. Data were analyzed through inductive content analysis approach. Themes and sub-themes that formed support sources and coping strategies were identified according to the analyses results. Accordingly, support sources were composed of the themes such as internal family strengths, extended family support, health team, social support, workplace support, and support from the institutions and organizations. Coping strategies included themes such as appraisal-focused, problem-focused, and emotion-focused themes. In conclusion, the present study revealed important clues about planning protective and supportive interventions for the families in a way to include medical health care providers.

Keywords: Childhood cancer, resilience, coping, family
\end{abstract}

Inonu University Journal of the Faculty of Education

Vol 22, No 2, 2021

pp. 1779-1805

DOI:

10.17679/inuefd.913012

Article type:

Research article

Received : 10.04.2021

Accepted : 30.08.2021

Suggested Citation

Usluoğlu,F. \& Atıcı, M. (2021). Experiences of families of children with cancer regarding support sources and coping strategies. Inonu University Journal of the Faculty of Education, 22(2), 1779-1805, DOI: 10.17679/inuefd.913012

The research was produced from the first author's doctoral dissertation and presented as an oral presentation at the 20th International Psychological Counseling and Guidance Congress, held in Samsun on October 25-27, 2018. 


\section{Kanser Hastası Çocuğu Olan Ailelerin Destek Kaynakları ve Başa Çıkma Stratejileri}

Feyruz Usluoğlu, Toros Üniversitesi, ORCID ID: 0000-0002-3012-1386

Meral Atıcı, Çukurova Üniversitesi, ORCID ID: 0000-0003-0675-4439

\section{Özet}

Bu araştırmanın amacı tedavisi devam eden kanser hastası çocukların anne, baba ve kardeşlerinin aile destek kaynakları ve bireysel başa çıkma stratejileri konusundaki görüşlerini incelemektir. Bu amaç için ölçüt örneklemeyle belirlenen, 12 aileden 24 ebeveyn ve 12 kardeş ile yüz yüze görüşmeler gerçekleştirilmiştir. Veriler tümevarım yoluyla ve içerik analizi yaklaşımıyla analiz edilmiştir. Analiz sonuçlarına göre destek kaynakları ve başa çıkma stratejilerini oluşturan tema ve alt temalar belirlenmiştir. Buna göre destek kaynakları; aile içi güçler, geniş aile desteği, sağılı ekibi, toplumsal destek, iş yeri desteği ve kurum-kuruluşların desteği temalarından oluşmuştur. Başa çıkma stratejileri ise değerlendirme-odaklı, problem-odaklı ve duygu-odakı başa çıkma temalarını içermektedir. Sonuç olarak bu çalışma, ailelere yönelik koruyucu ve destekleyici müdahalelerin tıbbi sağlık hizmet veren profesyonelleri de kapsayacak şekilde planlanması konusunda önemli ipuçları ortaya koymuştur.

Anahtar Kelimeler: Çocukluk çağı kanseri, başa çıkma, psikolojik dayanıklılı, aile

İnönü Universitesi

Eğitim Fakültesi Dergisi

Cilt 22, Sayı 2, 2021

ss. $1779-1805$

DOI:

10.17679/inuefd.913012

Makale Türü:

Araştırma Makalesi
Gönderim : 10.04.2021

Kabul : 30.08.2021

Önerilen Atıf

Usluoğlu,F. \& Atıcı, M. (2021). Kanser hastası çocuğu olan ailelerin destek kaynakları ve başa çıkma stratejileri. Inönü Üniversitesi Eğitim Fakültesi Dergisi, 22(2), 1779-1805, DOI: 10.17679/inuefd.913012

Araştırma, birinci yazarın doktora tezinden üretilmiş ve 25-27 Ekim 2018 tarihlerinde Samsun'da düzenlenen 20. Uluslararası Psikolojik Danışmanlık ve Rehberlik Kongresi'nde sözlü bildiri olarak sunulmuştur. 


\section{Experiences of Families of Children with Cancer Regarding Support Sources and Coping Strategies}

The Family System Theory suggests that a change in a family member affects all the family members,(Patterson et al., 2000) and thus when a child is diagnosed with cancer, the whole family is reported to be affected by the consequences of cancer (Jones et al., 2010). Cancer diagnosis, by challenging the belief of a long and happy life (Giammona \& Malek, 2002), causes family members to face an severe trauma (McCubbin et al.,2002) and to give various emotional reactions (Grootenhuis \& Last, 1997; Wong \& Chan, 2006; Beltrao et al., 2007; Zengin et al., 2012; D'Urso, et al., 2017).

Thanks to the improvements within the last 30 years including early diagnosis, clinical support, and cooperation in clinical studies, longevity and survival rates of children with cancer have increased (Hamre et al., 2003; O'Leary et al., 2008). In addition On the other hand, factors such as its being experienced in various stages and taking years have made cancer a chronic disease (Birol \& Akdemir, 2005). As a result, the family system meets new stressors and needs with the cancer diagnosis (Patterson et al.,2004; McCubbin et al., 2002). On the other hand, families mention some protective and supportive processes and factors such as important support sources and coping behaviours regarding the difficulties they have (McCubbin et al., 2002; wong \& Chan, 2006; Beltrao et al., 2007; Patterson \& Garwick, 1994; Patterson, 2002; Prchal \& Landolt, 2012).

\section{Purpose}

This study was based on The Family Adjustment and Adaptation Response (FAAR) Model. (Patterson \& Garwick, 1994). According to the model, a crisis situation encountered in the family, such as a chronic disease diagnosis, leads to demands caused by the stress and difficulties. By using the capabilities they protected and developed, the family makes an effort to maintain a balanced process against these demands met like a social system (Patterson \& Garwick, 1994; Patterson, 2002; Patterson, 1988). Family capabilities, family relational 
processes, personal and demographic features of the family members, and out of family supports are grouped as family's creating meaning and coping behaviours (Patterson et al., 2004; Patterson \& Garwick, 1994; Patterson, 2002; Patterson, 1988). In this regard, family capabilities are composed of features, qualities and competences individually from family members and as a unit and group from the family (Patterson, 2002). In the case of a childhood cancer disease, family capabilities are approached in two aspects as sources and coping behaviours. While the sources are composed of the sick child, family, society and the health system; coping behaviours are grouped as appraisal-focused, problem-focused, and emotionfocused coping behaviours (Patterson, 1994). The present study aims to identify support sources and coping behaviours of families who have a child with ongoing childhood cancer.

\section{Method}

\section{Design}

This study utilized a phenomenological approach, which is a qualitative method. The phenomenological approach is used to examine less-known areas or to investigate sensitive topics by focusing on the phenomena for which an in-depth and detailed understanding (Moustakas, 1994; Yıldırım \& Şimşek, 2011).

\section{Sampling Procedures and Participants}

The participants were selected according to the purposeful sampling method, which is based on a number of criteria (See Table 1).

\section{Table 1}

The Inclusion Criteria Used for the Selection of the Sick Children, Families, Parents and Siblings

(1) having received the cancer diagnosis at least three months before the date the study was conducted

(2) the child's having an ongoing treatment,

(3) the child's not being in the terminal stage,

(4) the child's not passing away during the time the interviews were conducted ,

(5) the parents' being the biological mothers and fathers of the sick child and living with their children in the process when the study was conducted,

(6) both parents' accepting to participate in the study,

(7) presence of at least one sibling apart from the child with cancer, 
(8) The family members' (parents or other children) having no chronic diseases that could be considered important or that might lead to function loss (e.g. mental deficiency or cancer in another family member),

(9) Siblings' being between 7 and 18 years old for the interviews and both parents' consenting for the interview.

The study included 12 families of 4 female and 8 male children with cancer (See Table

2). The sick children were having treatment at the time of the study. The study was conducted with 36 people, both parents from 12 families (12 mothers and 12 mothers) (See Table 3 ) and 12 siblings in eight of these families ( 6 sisters and 6 brothers) (See Table 4 ) who met the research criteria and who accepted to participate in the study.

Table 2

Characteristics of Children with Cancer

\begin{tabular}{|c|c|c|c|c|}
\hline Gender & $\mathrm{N}$ & $\%$ & Range & $\mathrm{X} / \mathrm{S}$ \\
\hline Female & 4 & 33,3 & & \\
\hline Male & 8 & 66,7 & & \\
\hline Age (years) & & & & $X=8.17 \mathrm{~S}=4.5$ \\
\hline 5- Less than 5 & 4 & 33,3 & $3-16$ & \\
\hline $6-10$ & 5 & 41,7 & & \\
\hline Over 10 & 3 & 25,0 & & \\
\hline \multicolumn{5}{|l|}{ Diagnosis } \\
\hline Leukaemia & 3 & 25,0 & & \\
\hline Lymphoma & 3 & 25,0 & & \\
\hline CNS tumours & 4 & 33,3 & & \\
\hline Bone tumours & 2 & 16,7 & & \\
\hline \multicolumn{5}{|c|}{ Time since diagnosis (months) } \\
\hline 3- 8 & 8 & 66,7 & $3,5-41$ & \\
\hline Over 8 & 4 & 33,3 & & \\
\hline \multicolumn{5}{|l|}{ Tretmant } \\
\hline $\mathrm{CT}$ & 4 & 33,3 & & \\
\hline CT-RT & 1 & 8,3 & & \\
\hline Surgery-CT & 6 & 50,0 & & \\
\hline Surgery-CT-RT & 1 & 8,3 & & \\
\hline \multicolumn{5}{|c|}{$\begin{array}{l}\text { Number of children in the } \\
\text { family }\end{array}$} \\
\hline $2-4$ & 10 & 83,3 & $2-11$ & \\
\hline Over 4 & 2 & 16,7 & & \\
\hline
\end{tabular}


Table 3

Characteristics of Parents

\begin{tabular}{|c|c|c|c|c|}
\hline Gender & $\mathrm{N}$ & $\%$ & Range & $\mathrm{X} / \mathrm{S}$ \\
\hline Female & 12 & 50 & & \\
\hline Male & 12 & 50 & & \\
\hline \multicolumn{5}{|l|}{ Age (years) } \\
\hline $32-39$ & 11 & 45,8 & $32-53$ & $41.50 / 6,15$ \\
\hline $40-49$ & 9 & 37,5 & & \\
\hline 50- 53 & 4 & 16,7 & & \\
\hline \multicolumn{5}{|l|}{ Education } \\
\hline No literate & 2 & 8,3 & & \\
\hline Literate & 3 & 12,5 & & \\
\hline Primary school & 7 & 29,2 & & \\
\hline Secondry school & 5 & 20,8 & & \\
\hline Hihg school & 5 & 20,8 & & \\
\hline college & 1 & 4,2 & & \\
\hline University & 1 & 4,2 & & \\
\hline \multicolumn{5}{|l|}{ Job } \\
\hline Regular worker & 9 & 37,5 & & \\
\hline İrregular/causal worker & 4 & 16,7 & & \\
\hline jobless & 11 & 45,8 & & \\
\hline \multicolumn{5}{|l|}{ Current occupation } \\
\hline Yes & 12 & 50 & & \\
\hline No & 12 & 50 & & \\
\hline \multicolumn{5}{|l|}{ Income } \\
\hline Less than 1000 & 2 & 8,3 & $500-5500$ & \\
\hline $1000-1800$ & 6 & 25,0 & & \\
\hline $2400-5500$ & 4 & 16,7 & & \\
\hline
\end{tabular}

Table 4

Characteristics of Siblings

\begin{tabular}{lllll}
\hline Gender & $\mathrm{N}$ & $\%$ & Range & $\mathrm{X} / \mathrm{S}$ \\
\hline Female & 6 & & & \\
$\begin{array}{l}\text { Male } \\
\text { Age (years) }\end{array}$ & 6 & & & \\
$7-12$ & 4 & 33,3 & $7-18$ & $13,33 / 2,70$ \\
$\begin{array}{l}13-18 \\
\text { Education }\end{array}$ & 8 & 66,7 & & \\
$\begin{array}{l}\text { Primary } \\
\text { school }\end{array}$ & 2 & 16,7 & & \\
$\begin{array}{l}\text { Secondry } \\
\text { schoo }\end{array}$ & 6 & 50,0 & & \\
Hihg school & 4 & 33,3 & & \\
\hline
\end{tabular}




\section{Data Collection}

Data were collected through face to face interview forms composed of semi-structured questions. The interviews were conducted by the first author, who is a psychologist specialized on family counselling, trauma and mourning. All the siblings and most of the parents were interviewed at home, some parents were interviewed either at their workplace or at the hospital where their child was treated. Each family member answered the interview questions separately. While the interviews conducted with the parents were completed in 35 minutes on the average, those conducted with siblings took 22 minutes on the average. All the interviews were video recorded.

\section{Data Analysis}

Data were analyzed using the inductive content analysis method. Analysis was performed in line with the analysis stages and method suggested by Dörnyei (2017) and Yıldırım and Şimşek (2011). Initially, interviews were transcribed word by word. Transcriptions were read repeatedly, and the lists of codes were identified. Then a temporary theme system was formed with the combination of different codes. This analysis process continued by coding the written data belonging to all participants separately (completing each family and moving to the other family). The codes in the analysis process were first done on paper, but later NVivo 11 qualitative analysis program was also utilized. Research data were analyzed according to three analysis units according to the sub-system within family: family as a whole, parents, and siblings.

\section{Trustworthiness}

The present study utilized a number of precautions based on the criteria suggested by Guba \& Lincoln (1982) in order to enhance trustworthiness. In this regard, for credibility, the study utilized data source triangulation; the researcher interacted with the participants for a long time, received expert and peer feedback. Transferability was enhanced by using purposeful sampling method, providing detailed explanation of the participant features and 
making intensive descriptions. Dependability was enhanced by conducting interviews with interview forms and video recording them, performing coding-recoding procedures for the data in the analysis phase, performing independent coding for the analysis of some data, and having two experts out of peers and research teams for supervising the plan and conduct of the research. For conformability, results that were supported with quotes were presented to expert supervision.

\section{Ethical Considerations}

Prior to the study, ethics committee approval was obtained from Cukurova University Medical Faculty Non-Interventional Clinical Studies Ethics Committee (04.12.2015/48/39). For the informed consent prior to the interviews, the participants were given information about the potential risks and benefits in written and verbal forms based on their age. Pseudo-names were used instead of real names of the participants while recording, analyzing, and storing the data; and the video records were kept confidential.

\section{Findings}

Results were grouped under support sources and coping behaviours dimensions, and the sub-themes that formed these two dimensions were identified.

\section{Support Sources}

The support sources were grouped as the themes, and the support types provided from these sources were grouped as the sub-themes.

\section{Support Sources Reported by the Parents}

The parents mentioned support provided from the internal family strengths, extended family, health team, parents having a child with cancer, society, workplaces and institutions and organizations (See Table 5). 
Table 5

Support Sources Reported by the Parents

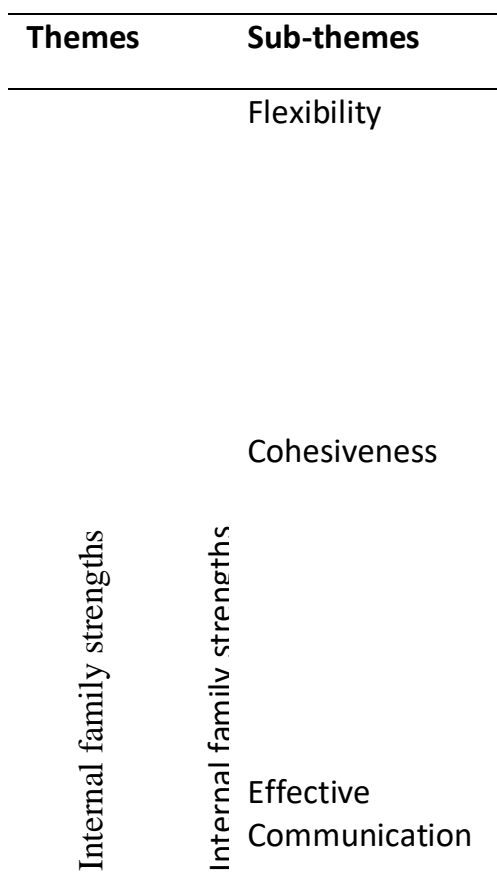

\section{Description of the experiences}

"We were all bunched together... Our children were not like children anymore, they were like mothers, fathers or elder brothers and sisters" (Mother 1).

My husband did not show much interested in his children before. He began to be more interested... He began to deal with some housework when I was not at home... (Mother 3).

We supported each other with my husband, we became each other's cure... We were trying to cheer each other up (Mother-4)

As a family, we tried to support each other and provide moral support (Father-9).

In fact, our relationships got much stronger; we began to share more things with each other (Mother-1).

We did not know much about this disease... We were just hearing its name, but we did not know what kind of a disease it was. We talked about it with my husband all the time. We were wondering whether she'd get better, whether the medicine would work, and whether we should take her to other cities because Adana did not seem to provide the treatment... Then we decided to do whatever the doctors told us to do (Mother-4).

Family meanings We prayed all the time, we used the word recovery in our prayers (Mother-2).

\begin{tabular}{|c|c|c|}
\hline 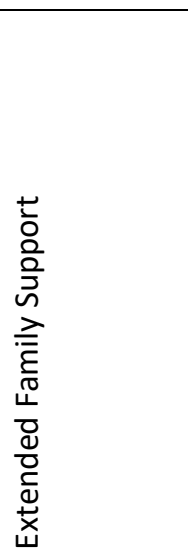 & $\begin{array}{l}\text { Social-emotional } \\
\text { support, helping } \\
\text { about parents' } \\
\text { responsibilities, } \\
\text { participating in } \\
\text { the treatment, } \\
\text { providing } \\
\text { financial support, } \\
\text { providing } \\
\text { vehicles for } \\
\text { transportation, }\end{array}$ & $\begin{array}{l}\text {...our relatives supported us greatly...they helped and provided with } \\
\text { moral support, too of the children when necessary... they tried to help } \\
\text { us to relax, they took responsibilities (Father-11). } \\
\text { My parents provide us with moral and material support. My mother } \\
\text { comes to hospital with me, stays with Kader (Mother-4). }\end{array}$ \\
\hline 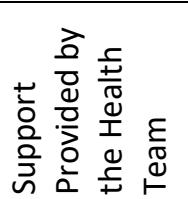 & $\begin{array}{l}\text { Respectful- } \\
\text { diligent attitudes }\end{array}$ & $\begin{array}{l}\text {.... Our nurses and doctors were very supportive. Really, you feel like } \\
\text { they are hugging you at the moment you enter the hospital building. } \\
\text { The care shown to you and to your child makes you feel relieved } \\
\text { (Mother-1). }\end{array}$ \\
\hline
\end{tabular}


Instilling hope

Guiding and informative
From the moment I learned the diagnosis, I viewed it as an incurable disease, but I asked all the questions in my mind to our doctor in Istanbul... He said we would overcome this disease because they could save 2 in every 3 children (Mother-12).

Our doctors and nurses made some recommendations... They listed a number of things that increase white blood cell or red blood cell. We acted according to their recommendations, and the values were going well in that period (Father-1).

\begin{tabular}{|c|c|c|}
\hline 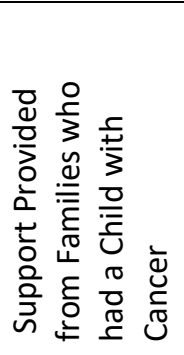 & $\begin{array}{l}\text { Informing- } \\
\text { advising, } \\
\text { cooperation and } \\
\text { guidance }\end{array}$ & $\begin{array}{l}\text { We were trying to guide each other during the times we could think no } \\
\text { more. She was saying "You should not do this; be careful about this; use } \\
\text { this medicine, etc." If she had the medicine I could not find, I used hers. } \\
\text { Both guidance and cooperation (Mother-5). }\end{array}$ \\
\hline $\begin{array}{l}\frac{t}{0} \\
\frac{0}{2} \\
\frac{0}{3} \\
\frac{\pi}{0} \\
0\end{array}$ & $\begin{array}{l}\text { Social-emotional } \\
\text { support } \\
\text { financial support } \\
\text { dealing with } \\
\text { house work } \\
\text { and providing } \\
\text { vehicle for } \\
\text { transportation }\end{array}$ & $\begin{array}{l}\text { Kith and kin, everyone was with us. They took care of the child, they } \\
\text { stood with us. They shared their food. They cooked Fatma's favorite } \\
\text { food. They visited us at hospital. Seeing them and talking with them } \\
\text { made me feel relieved (Mother-12). } \\
\text { They provided some financial support; they gave us a ride while we } \\
\text { were going to the hospital (Father-8). }\end{array}$ \\
\hline 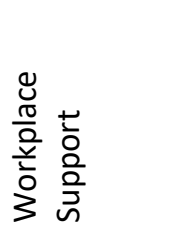 & $\begin{array}{l}\text { Flexible working } \\
\text { hours } \\
\text { giving cash } \\
\text { advance }\end{array}$ & $\begin{array}{l}\text { Every week I asked for permission to take my child to the doctor } \\
\text { (Father-10). } \\
\text { When I needed money, they gave cash advance. They did not let me } \\
\text { run out of money. I go to hospital three times a week; they always } \\
\text { provided full support about permission (Father-8). }\end{array}$ \\
\hline
\end{tabular}

\section{Internal Family Strengths}

Almost all of the parents (21 parents from 12 families) mentioned the presence of one of the sub-themes forming internal family strengths which included family flexibility, cohesiveness, effective communication, family meanings, financial sufficiency, and mother's profession. Parents who stated opinions about flexibility ( 8 parents from 4 families) mentioned domestic cooperation, father's taking new responsibilities, and sibling support. The new responsibilities taken by the family members provided the support to decrease one another's burden. 
In the Family Cohesiveness support type, the parents emphasized that their cohesiveness increased in ways like sharing parents' responsibilities and providing support to each other, and their domestic relationships got more powerful as a whole.

Effective Communication; involved behaviours like talking about the illness, making decisions about the treatment, and sharing experiences.

Another support source mentioned by the families was "family meanings", which was composed of positive approach and maintenance of hope, trust in God, seeing this process as a test, and praying with a religious approach in family environments.

\section{Extended Family Support}

All the families and more than two-third of the parents $(n=20)$ mentioned the extended family support. These support sources were social-emotional support, helping about parents' responsibilities, participating in the treatment, cooking-cleaning; providing financial support, providing vehicles for transportation, and clothing support. The parents stated that the social-emotional support of distant relatives were mainly calling, visiting, praying and saying good wishes, sharing emotions, and taking care of the sick child.

\section{Support Provided by the Health Team}

Supports provided by the health team were mentioned by three-fourth of the families $(n=9)$ and half of the parents $(n=12)$. Sub-themes of this support included the health team's "respectful-diligent attitudes, instilling hope, and providing information-guidance".

Another support provided by the health team was related to their instilling hope by giving information, making comparisons between the disease groups and/or giving statistical data. Finally, parents reported guiding and informative support behaviours of the health team such as explaining the causes of the disease, informing about the fight against the disease, and providing documents about it. 


\section{Support Provided from Families who had a Child with Cancer}

More than one-third of the parents stated opinions regarding this theme including two sub-themes of informing-advising and cooperation and guidance. Informing-advising and cooperation sub-theme consisted of "information about the things to be experienced, requirements for fighting the disease and providing emotional support.

\section{Social Support}

Approximately three-fourth of the parents stated opinions about support from the society. Social support usually involved friends of family members and neighbors who provided mainly social-emotional support, financial support, dealing with house work and providing vehicle for transportation. Social-emotional support was reportedly composed of support provided from the siblings' friends, parents' friends and neighbors by asking about the status of the sick child, offering material and moral support, calling, praying and saying good wishes, standing by the parents and not leaving them alone, dealing with the sick child, cooking the sick child's favorite food, cooking for the child and family, visiting at hospital, giving suggestions for the parents, and giving positive and hopeful prompts.

\section{Workplace Support}

As it is demonstrated in the quotes below, workplace support theme was composed of support types defined as flexible working hours and/or giving cash advance.

\section{Institutions and Organizations}

Support provided from institutions and organizations was mentioned by one-fourth of the parents. The first one was financial support provided by the Provincial Social Assistance and Solidarity Foundation once and/or on regular basis (money for care).

The second one was support behaviours such as fun and trip programs organized by nongovernmental organizations, clothing and food support provided to the family, financial support provided once or at certain intervals, and one private school's undertaking the sick child's education. 


\section{Support Sources Reported by the Siblings}

Like parents, siblings also mentioned internal family strengths, extended family

support, social support, institutions and organizations, and workplace support (See Table 6).

\section{Table 6}

Support Sources Reported by the Siblings

\begin{tabular}{|c|c|c|}
\hline Themes & Sub-themes & Description of the experiences \\
\hline & Family cohesiveness & $\begin{array}{l}\text { We became more connected to each other... Now we can talk } \\
\text { about everything (Sister-4) } \\
\text { Everyone started to behave each other more positively. We } \\
\text { haven't been shouting each other for two years I guess... In the } \\
\text { past, I could not shape my hair as I wanted, I was doing it as my } \\
\text { dad wanted me to do. Now I can do however I want. My dad says } \\
\text { nothing anymore (Brother-9). }\end{array}$ \\
\hline $\begin{array}{l}\text { Internal } \\
\text { family } \\
\text { strengths }\end{array}$ & & \\
\hline
\end{tabular}

Effective

communication

Family meanings
When my sister was out of the intensive care unit, they felt happy and shared the news with me. I felt happy, too (Brother-6).

"We were highly hopeful... We knew God always had hopes for us, so we always prayed (Sister-10).
Social-emotional

support

Extended

Family

Support
Care of the siblings

Participating in the treatment

Cooking and cleaning
My aunts from both sides generally provided so much emotional support. They always tried to help us to pour out our feelings. They stood by us, they called us frequently, and they tried to come to the hospital (Sister-1).

When my mother came from hospital at late hours, they went to my aunt's house. She cooked for them (Brother-1).

We do not have a car... My uncle took us to hospital (Brother-9). For instance, since my dad did not work then, we had little money. My grandfather and uncle gave us money; they bought food for us (Brother-6). 
taking the responsibilities of the parents

Providing financial and vehicle support.

$\begin{array}{ll}\begin{array}{c}\text { Social } \\ \text { Support } \\ \text { of the siblings }\end{array} & \begin{array}{l}\text { Teachers and friends } \\ \text { my sister was sick (Brother- 6). }\end{array} \\ \begin{array}{l}\text { Support from the } \\ \text { neighbors }\end{array} & \begin{array}{l}\text { There were a number of people who came from Hajj, they } \\ \text { brought zam-zam water. Neighbors constantly asked about the } \\ \text { treatment, they visited us at home, they spoke with my mum and } \\ \text { supported her (Brother- 1). } \\ \\ \ldots \text { We have a neighbor from our village. My dad borrows money } \\ \text { from him when he is in need (Sister-9). }\end{array}\end{array}$

\begin{tabular}{ll}
\hline $\begin{array}{l}\text { Institutions } \\
\text { and } \\
\text { Organizations }\end{array}$ & $\begin{array}{l}\text { They send a package of support items from the Municipality" } \\
\text { (Brother- 7) }\end{array}$ \\
\hline Workplace & "They send us a package for support from my workplace" \\
Support & (Brother- 7).
\end{tabular}

\section{Internal Family Strengths}

Siblings mentioned the presence of sub-themes such as family cohesiveness, family meanings, and communication. Family cohesiveness was composed of the behaviours such as parents' support for the siblings, being more interested and more understanding in the daily life problems, being more permissive, and demonstrating behaviours to make family members happy. The siblings also stated that the relationships between the family members got stronger, and family members began to be more tolerant in the family.

All of the siblings stated opinions about one of the behaviours that formed family cohesiveness. 
Effective communication was composed of the views regarding parents' sharing the status of the sick child with siblings.

Other family meanings as internal family strengths included maintenance of hope and religious views.

\section{Extended Family Support}

Three-fourth of the siblings mentioned the extended family support. These supports included social-emotional support given to the parents, care of the siblings, participating in the treatment, cooking and cleaning, taking the responsibilities of the parents, and providing financial and vehicle support. Social-emotional support included extended family members' behaviours such as calling, visiting them at home or at hospital, and making some suggestions for instilling hope.

Other supports provided by the extended families included taking care of the children, helping with cooking and cleaning, providing vehicles for transportation, and participating in the treatments.

\section{Social Support}

Half of the siblings mentioned views regarding this theme. The theme included support behaviours from the friends and teachers of the siblings and social environment of the family. Teachers and friends of the siblings demonstrated behaviours such as showing interest, instilling hope, and providing an environment out of the focus of the disease.

Support from the neighbors included social-emotional support for the parents and lending money. Social-emotional support behaviours of the neighbors included prayers and good wishes, asking for the status of the sick child, and supporting the family with home visits. 


\section{Coping Strategies}

\section{Parents' Coping Strategies}

Coping behaviours used by the parents in order to cope with the stress and difficulties caused by the disease were grouped under the "problem-focused behaviours, appraisalfocused behaviours, and emotion-focused behaviours" themes (See Table 7).

Table 7

Parents' Coping Strategies

\begin{tabular}{|c|c|c|}
\hline Themes & Sub-themes & Description of the experiences \\
\hline $\begin{array}{l}\text { Problem- } \\
\text { Focused } \\
\text { Coping } \\
\text { Behaviours }\end{array}$ & $\begin{array}{l}\text { Seeking } \\
\text { information }\end{array}$ & $\begin{array}{l}\text { I asked questions to the doctors when I was confused about something. } \\
\text { When I read from the internet I learned that cancer was not a disease that } \\
\text { would kill instantly. I realized that it could be possible to overcome with } \\
\text { moral and motivation... This gave us hope (Father } 3 \text { ). }\end{array}$ \\
\hline $\begin{array}{l}\text { Appraisal- } \\
\text { Focused } \\
\text { Coping } \\
\text { Behaviours }\end{array}$ & Positive views & $\begin{array}{l}\text { When my child was taken to the operation, the doctor said there was } 80 \% \\
\text { of chance for losing him and } 20 \% \text { of chance for survival. He gave me hope, } \\
\text { there was a hope for } 20 \% \text { survival. I believed in this. I thought he could } \\
\text { overcome this (Father-6). } \\
\text { When you enter the hospital building, you see children in worse conditions } \\
\text { than your child and you feel grateful. We saw friends who completed their } \\
\text { treatment. We felt hopeful when we saw them. We tried to feel good } \\
\text { believing that we would also see such days (Mother-1). } \\
\text { After I saw the other patients I thought that we had nothing important. I } \\
\text { started to feel relieved (Father- } 8 \text { ). }\end{array}$ \\
\hline
\end{tabular}

Religious view If God gave us this disease, he would give its solution of course, this is how we thought (Father 4).

I say this is our destiny, I mean it is a test from our God (Father-6). 


\begin{tabular}{|c|c|c|}
\hline & $\begin{array}{l}\text { Religious } \\
\text { rituals }\end{array}$ & $\begin{array}{l}\text { I pray for my child till morning, I tell my beads, I say salavat, I perform } \\
\text { prayer (Mother 10). } \\
\text { I pray every day, I read Koran. When I read Koran I feel relieved and } \\
\text { become stronger, I feel better morally (Father-1). }\end{array}$ \\
\hline \multicolumn{3}{|l|}{$\begin{array}{l}\text { Emotion- } \\
\text { focused } \\
\text { Coping }\end{array}$} \\
\hline \multirow[t]{2}{*}{ Behaviours } & $\begin{array}{l}\text { Seeking } \\
\text { social- } \\
\text { emotional } \\
\text { support }\end{array}$ & $\begin{array}{l}\text { I visit my neighbor for a couple of minutes... we are talking for a while.... I } \\
\text { am talking with my husband; I share with him (Mother- 8) } \\
\text { Talking with friends makes me feel good. I feel relieved when I talk or go } \\
\text { somewhere with someone... I share everything mainly with my parents } \\
\text { (Mother -1). }\end{array}$ \\
\hline & $\begin{array}{c}\text { Activities and } \\
\text { work life }\end{array}$ & $\begin{array}{l}\text { I realized that the disease was suffocating me. I was drowned in it... I } \\
\text { decided to start working because I realized that I would not be able to go } \\
\text { on like that (Mother }-5 \text { ). } \\
\text { Well, the problems in my head do not get worse if I am busy with } \\
\text { something and if I can concentrate on it (Father -12). }\end{array}$ \\
\hline
\end{tabular}

\section{Problem-Focused Coping Behaviours}

Three-fifth of the parents were found to demonstrate problem-focused coping strategies behaviours by seeking information from the internet, doctors, books, experts, and friends.

Other problem-focused coping behaviours included finding someone to take care of the child to relieve the care burden in the family, participating in the TV programs to find medulla, and a mother's asking for support from teachers regarding the problems at school for the healthy child that she ignored because of the treatment of the sick child.

\section{Appraisal-Focused Coping Behaviours}

Almost all of the parents stated views about the Appraisal-focused Coping behaviours. Positive views of the parents included (17 parents from 10 families) believing in the child's overcoming the disease, making comparisons, drawing positive conclusions, hoping about the situation, and types of beliefs about the treatment options. 
Religious views of trusting in God, leaving decision to God, believing that diseases and solutions came from God were mentioned by 13 parents from 10 families it included trust in God, leaving decision to God, believing that everything including diseases and solutions came from God, and thinking that this process was a test.

Other appraisal-focused coping behaviours included focusing on now, accepting the disease, generalizing the status of the disease, and minimizing the disease behaviours.

\section{Emotion-focused Coping Behaviours}

Almost all of the parents reported to have used emotion-focused behaviours. Threefourth of the parents performed religious rituals (praying, reading Koran, visiting religious places, taking a vow, etc.) with the purposes of getting relieved and helping the child to feel relieved.'

Another coping behaviour was seeking social-emotional support in order to share and receive support for the negative emotions such as "pouring out their grief" "speaking" "chatting", and "expressing emotions" to friends, extended family members, neighbors, and spouse.

The parents also mentioned the contributions of activities and work life on coping such as focusing on work, going out of house alone, keeping themselves busy with a hobby, or doing an activity with the family.

Other emotion-focused coping behaviours were keeping strong by emphasizing the parent roles, professional help, smoking hiding difficult emotions, taking care of oneself, and changing the focus of the mind.

\section{Coping Behaviours of The Siblings}

Like parents, siblings also demonstrated various behaviours to cope with the stress and difficulties emerging in this process, which were collected under appraisal-focused, problemfocused, and emotion-focused behaviours themes (See Table 8). 


\section{Table 8}

Coping Behaviours of The Siblings

\begin{tabular}{|c|c|c|}
\hline Themes & Sub-themes & Description of theexperiences \\
\hline \multirow[t]{2}{*}{$\begin{array}{l}\text { Appraisal- } \\
\text { Focused } \\
\text { Coping } \\
\text { Behaviours }\end{array}$} & $\begin{array}{l}\text { Positive } \\
\text { views }\end{array}$ & $\begin{array}{l}\text { I had a friend who had cancer, she lost her hair, but then doctors found a } \\
\text { solution. She became better. Now she comes to school regularly. She is okay } \\
\text { now, she's getting better... I think that my sister will also recover like my } \\
\text { friend (Brother- 7). }\end{array}$ \\
\hline & Minimizing & Well, I thank God. Worse things might have happened (Sister-4). \\
\hline \multirow{4}{*}{$\begin{array}{l}\text { Emotion- } \\
\text { Focused } \\
\text { Coping } \\
\text { Behaviours }\end{array}$} & $\begin{array}{l}\text { Social } \\
\text { support }\end{array}$ & I had a good friend... I was sharing my emotions with her (Sister-10). \\
\hline & $\begin{array}{l}\text { Socialization- } \\
\text { Activities }\end{array}$ & $\begin{array}{l}\text { Going out alone makes me feel good (Sister-7). } \\
\text { Sometimes I join school trips. I spend time with my friends and other } \\
\text { siblings, play games out (Brother-6). }\end{array}$ \\
\hline & $\begin{array}{l}\text { Religious } \\
\text { practices }\end{array}$ & $\begin{array}{l}\text { I started to perform prayers at that time. I was praying all the time (Brother- } \\
\text { 1). }\end{array}$ \\
\hline & $\begin{array}{l}\text { Changing the } \\
\text { focus of the } \\
\text { mind; }\end{array}$ & $\begin{array}{l}\text { I usually watch movies, read books, and listen to music in order to feel } \\
\text { relieved. I listen to music. I mean, my emotions are changeable. I am trying } \\
\text { to be happy (Sister-3). }\end{array}$ \\
\hline $\begin{array}{l}\text { Problem- } \\
\text { Focused } \\
\text { Coping } \\
\text { Behaviours }\end{array}$ & $\begin{array}{l}\text { Seeking- } \\
\text { information }\end{array}$ & $\begin{array}{l}\text { I searched in the internet... I was talking with my chef in my apprenticeship } \\
\text { place. One of his relatives is a doctor, I talked with him a couple of times. I } \\
\text { was talking with the counsellor at my school (Sister-9). }\end{array}$ \\
\hline
\end{tabular}

\section{Appraisal-Focused Coping Behaviours}

Siblings ( 3 siblings from 3 families) reported to have positive views and used minimizing for appraisal-focused coping behaviours. Positive views ( 2 siblings from 2 families) were composed of two types of behaviours including concluding something positive from comparisons and maintaining hope.

Minimizing is an appraisal for decreasing the effect of a situation by thinking that worse cases might happen. 


\section{Emotion-Focused Coping Behaviours}

All of the siblings reported to have used one of the emotion-focused coping behaviours such as use of social-emotional support, socialization- activities, religious practices, changing the focus of the mind, dreaming, and showing interest in the sibling.

Use of Social Support: Social support composed of the behaviours of sharing the sibling's experiences and emotions in the disease process. Siblings reported to share their feelings with their friends and extended (cousins and aunts) or nuclear (mother) family members.

Socialization-Activities: Socialization and activities were composed of siblings' out-of home activities after the diagnosis, either alone or with their friends.

Religious practices; religious practices were composed of behaviours such as praying and performing prayer (4 brothers from 3 families).

Changing the focus of the mind; those behaviours mentioned by 8 siblings from 6 families included playing computer games, focusing on lessons, watching movies, listening to music, spending time on social media, and reading books. The most frequently mentioned behaviour was reading books ( 6 siblings).

Other emotion-focused coping behaviours included behaviours such as dreaming, showing interest in the sick child, avoiding the sick child, and hiding difficult emotions.

\section{Problem- Focused Coping Behaviours}

Problem- focused coping behaviours were composed of information-seeking behaviours from internet and experts regarding how to treat the sick child.

\section{Discussion \& Conclusion}

The present study investigated the support sources, types of support from these sources, and coping behaviours that helped families who had a child with cancer to feel better and to cope with this situation.

Studies that investigated endurance in families who had a child with cancer emphasized internal family strengths and family sources (Patterson et al., 2004; McCubbin et 
al., 202). Results of the present study showed that parents mentioned the presence of any one of the internal family strengths that included flexibility, cohesiveness, and effective communication of the family, family meanings, financial sufficiency, and mother's profession. As for siblings, they stated views about cohesiveness of the family, mainly meanings and communication. The parents emphasized that their intimacy increased in their relationships, which provided support and strengthened the family relationships. In a similar vein, siblings stated that the relationships between family members got stronger, and as a whole they needed to become more tolerant in the family environment. These results are in line with other studies in literature which showed that family members supported each other (Beltrao et al., 2007); other parallel findings were siblings' views indicating that after the severe disease they experienced cohesiveness, and family ties got stronger (Prchal \& Landolt, 2012). In addition, statements of the parents and siblings seemed to be in line with the statements that endurance should involve not only resistance against difficult conditions but also the ability of growing and improving under difficult conditions (Truffino, 2010).

Extended family support was a support source reported by the parents (Patterson et al.,2004; Brody \& Simmons, 2007). It was reported to provide various assistance types such as helping the parents to relax by taking responsibilities in siblings' school and parents' work, and providing vehicle for transportation and emotional support (McCubbin et al., 2002). More than two-third of the parents and three-fourth of the siblings mentioned the extended family support.

Support types provided by the health provider team were reported by three-fourth of the families and half of the parents. Respectful-diligent attitudes of the health team enhanced trust in the health team and encouraged parents' health-seeking behaviours from the doctors; these attitudes were felt as social-emotional support by the parents during those fragile times. Providing parents with guidance and informative materials helped them to decrease the feelings of uncertainty and helplessness and increase the sense of control about fight against 
the disease. Health team was reported to be a support source for families (Patterson et al.,2004; McCubbin et al., 2002; Beltrao et al., 2007; Brody \& Simmons, 2007). Especially families were reported to feel highly connected to the team that provided health service to save their child, and they desperately needed trust and realistic hope during these fragile times (McCubbin et al., 2002).

Patterson et al. (2004) reported the support provided by other parents who experienced childhood cancer. Support from the parents who overcame this disease or who lost their child due to this disease was found to be a support source for the parents in this study. These support types provided assistance in understanding a situation, making changes in the assessments, seeking new treatment options, increasing the feeling of control, and using new behaviours for coping.

Another important support source for the parents was social support. Majority of the parents mentioned the social-emotional support from friends of family members and neighbors, financial support, dealing with house work, and providing vehicle for transportation. In a similar vein, majority of the participating siblings mentioned the emotional support they were provided from their teachers and friends and the support provided to the sick child by their neighbors. Studies in the field also reported social support sources for the family (Patterson et al., 2004; McCubbin et al.,2002; Beltrao et al., 2007). Parents reported that such support was provided by people from the church, their friends and colleagues, their children's peers and friends from school (Patterson et al., 2004); siblings reported that such support was provided from friends and professionals ( $\left.D^{\prime} U r s o, 2017\right)$. This support was reported to be through empathy, intensive emotional support, and financial support (McCubbin et al., 2002).

Types of support provided from the workplace were reported by two parents and one sibling in the present study. McCubbin et al. (2002) reported the critical components of 
workplace support as flexible working hours, staying with the child, and leaving job or job security after a long time absence.

The support received from the institutions and organizations was stated by nearly onefourth of the parents and one sibling. Especially financial support is an important type of support for parents in order to maintain the treatment and decrease the feelings of helplessness. In a similar vein, Lakkis et al. (2016) reported that the financial support given to families was a protective factor especially for the mothers.

Family members' individual coping strategies are another important aspect of families' well-being. One-third of the families used some problem-focused coping behaviours majority of which aimed to seek information for decreasing uncertainty. Similarly, studies in literature reported that parents who had a child with cancer demonstrates coping behaviours in the form of seeking information (Patterson et al., 2004; Wong \&Chan, 2006). Almost all of the parents demonstrated behaviours that could be considered as appraisal-focused behaviours. Parents maintained hope with positive views; endured the disease with a religious point of view and patience and experienced the feeling of having done the best they could by trusting in a divine source. Studies in the field reported that parents used similar appraisal-focused coping behaviours (Patterson et al., 2004; Wong \&Chan, 2006; Yeh et al., 2000).

Another coping strategy used by almost all of the participating parents was emotionfocused behaviours. These coping behaviours were used in order to feel relieved and were considered to contribute to the child's coping with the disease. Some examples included religious rituals; sharing the negative emotions and seeking social-emotional support; becoming strong for the other members of the family; returning to job and focusing. These findings were found to be similar to the studies on emotion-focused coping behaviours in literature (Patterson et al., 2004; Wong \&Chan, 2006; Yeh et al., 2000).

Like parents, some siblings also used some problem-focused and evaluation-focused coping behaviours. On the other hand, all the siblings used emotion-focused coping behaviours 
such as social-emotional support, socialization-activities, religious practices, changing the mind, dreaming, and showing interest in the sick child. Siblings' using social-emotional support and socialization-activities coping behaviours were in line with the studies in literature (D'Urso et al., 2017). Another parallel finding with the related literature suggesting that friends are important sources for sharing emotions and maintaining a normal life by moving away from the focus of the disease (Prchal \& Landolt, 2012). In conditions like cancer in which the status cannot be changed, people use coping behaviours without changing the threatening case but decreasing or controlling the emotions, maintaining well-being, and coping (Patterson et al., 2004; Yeh et al., 2000; Folkman, 2008; Hamama et al., 2000; Murphy et al., 2008). Findings showed that both parents and siblings used appraisal-focused and/or emotion-focused coping behaviours instead of problem-focused coping behaviours. In addition, among these appraisalfocused behaviours, mainly religious rituals were found to be used by the parents; use of socialization-activities and changing the focus of the mind were found to be used mainly by the siblings.

This study has a number of limitations. The first one is not involving siblings at preschool period or over 18 , health professionals, or the siblings' teachers. Secondly, diagnosis and diagnosis time of children were different from each other. Finally, the study did not investigate the effects of ethnicity including culture, losses due to cancer in the extended family, and personal characteristics.

In conclusion, despite the limitations, this study made significant contributions to the understanding of the protective or supportive factors of families living with childhood cancer disease. In this regard, this study provided important clues about planning and supportive approaches and planning of psychological interventions for families, including medical health care provides. For example, psychologists can carry out psychoeducational studies that aim to provide information on the causes of illness, the process of illness, and the needs of the family. In addition, school counselors can plan interventions for siblings' needs. It is important that 
these interventions to be provided are based on the protective factors that the family and family members have, or that they are made in a way that supports these protective factors.

\section{Conflict of interest}

The authors declared no potential conflicts of interest with respect to the research, authorship, and/or publication of this article.

\section{Funding}

This study is a part of PhD dissertation which was supported by Cukurova University of Scientific Research Projects Coordination Unit (SDK-2016-5608).

\section{Ethical Considerations}

Prior to the study, ethics committee approval was obtained from ........University Medical Faculty Non-Interventional Clinical Studies Ethics Committee (04.12.2015/48/39). 


\section{References}

Beltrao, M.R. L, Vasconcelos, M.G., Pontens, C.M.,\& Albuquerque, M.C.(2007). Childhood cancer: maternal perceptions and strategies for coping with diagnosis. J Pediatr (Rio J), 83(6): 552-566. http://dx.doi.org/10.1590/S0021-75572007000800014

Birol, L., \& Akdemir, N. (2005). İç hastalıkları ve hemşirelik bakımı. Sistem Ofset Baskı.

Brody, A. C., \& Simmons, L. A. (2007). Family resilience during childhood cancer: the father's perspective. J Pediatr Oncol Nurs, 24(3): 152-165. https://doi.org/10.1177/1043454206298844

D’Urso, A., Mastroyannopoulou, K.,\& Kirby, A.(2017). Experiences of posttraumatic growth in siblings of children with cancer. Clin Child Psychol Psychiatry, 22(2): 301-317. https://doi.org/10.1177/1359104516660749

Dörnyei, Z.(2007). Research methods in applied linguistics. Oxford.

Folkman, S.(2008). The case for positive emotions in the stress process. Anxiety Stress Coping, 21(1): 3-14. https://doi.org/10.1080/10615800701740457

Giammona, A. J., \& Malek, D.M.(2002). The psychological effect of childhood cancer on families. Pediatr Clin North Am., 49(5): 1063-1081. https://doi.org/10.1016/s00313955(02)00036-6

Grootenhuis, M. A.,\& Last, B. F.(1997). Adjustment and coping by parents of children with cancer: a review of the literature. Support Care Cancer, 5(6): 466-484. https://doi.org/10.1007/s005200050116

Guba, E. G.,\& Lincoln, Y. S.(1982). Epistemological and methodological bases of naturalistic inquiry. Educational Communication and Technology, 30(4): 233-252. ISSN 0148-5806

Hamama, R., Ronen, T.,\& Feigin, R.(2000). Self-control, anxiety, and loneliness in siblings of children with cancer. Soc Work Health Care. 31(1): 63-83. https://doi.org/10.1300/J010v31n01_05

Hamre, M. R, Williams, J., Chuba, P., Bhambhani, K., Ravindranath, Y., \& Severson, R. K.(2003). Early deaths in childhood cancer. Pediatr Blood Cancer, 34(5): 343-347. https://doi.org/10.1002/(SICI)1096-911X(200005)34:5<343::AID-MPO5>3.0.CO;2-B

Jones, B., Volker, D., Vinajeras, Y., Butros, L., Fitchpatrick, C., \& Rosetto, K. (2010). The meaning of surviving cancer for Latino adolescents and emerging young adults. Cancer Nurs, 33(1): 74-81. doi: 10.1097/NCC.0b013e3181b4ab8f

Lakkis, N. A., Khoury, J. M., Mahmassani, D. M., Ramia, M. S., \& Hamadeh, G. N. (2016). Psychological distress and coping strategies in parents of children with cancer in Lebanon. Psychooncology, 25 ( 4): 361-480. https://doi.org/10.1002/pon.3934

Lazarus, R. S.,\& Folkman, S. (1984). Stress, appraisal and coping. Springer.

McCubbin, M., Balling, K., Possin, P., Frierdich, S., \& Bryne, B. (2002). Family resiliency in childhood cancer. Fam 103-111. https://doi.org/10.1177/1043454206298844

Murphy, B. L. M., Flowers, S., McNamara, K. A., \& Young-Saleme, T. (2008). Fathers of children with cancer: involvement, coping, and adjustment. J Pediatr Health Car, 22(3): 182-9. https://doi.org/10.1016/j.pedhc.2007.06.003

Moustakas, C. (1994). Phenomenological research methods. Thousand Oaks: Sage. 
O'Leary, M., Krailo, M., Anderson, J. R., \& Reaman, G. H. (2008). Progress in childhood cancer: 50 years of research collaboration, a report from the children's oncology group. Semin Oncol, 35(5): 484-93. https://doi.org/10.1053/j.seminoncol.2008.07.008

Patterson, J. M.,\& Garwick, A.W. (1994). The impact of chronic illness on families: a family systems perspecttive. Ann Behav Med, 16(2): 131-142. https://doi.org/10.1093/abm/16.2.131

Patterson, J. M., Holm, K. E., \& Gurney, J. G.(2004). The impact of childhood cancer on the family: a qualitative analysis of strains, resources, and coping behaviors. Psychooncology, 13(6): 390-407. https://doi.org/10.1002/pon.761

Patterson, J. M.(1988). Families experiencing stress: I. The Family Adjustment and Adaptation Response Model: II. Applying the FAAR Model to health-related issues for intervention and research. Fam Syst Med, 6(2): 202-237. https://doi.org/10.1037/h0089739

Patterson, J. M. (2002). Integrating family resilience and family stress theory. J Marriage Fam, 64(2): 349-360. https://doi.org/10.1111/j.1741-3737.2002.00349.x

Prchal, A., \& Landolt, M. A.(2012). How siblings of pediatric cancer patients experience the first time after diagnosis: A qualitative study. Cancer Nurs, 35(2): 133-140. doi: 10.1097/NCC.0b013e31821e0c59

Truffino, J. C.(2010). Resilience: an approach to the concept. Rev Psiquiatr Salud, 3(4): 145-151. doi: 10.1016/j.rpsm.2010.09.003

Wong, M. Y-F.,\& Chan, S. W-C.(2006). The qualitative experience of Chinese parents with children diagnosed of cancer. J Clin Nurs, 15(6): 710-717. https://doi.org/10.1111/j.13652702.2006.01297.x

Wright, L. M.,\& Leahey, M.(2000). Nurses and families: A guide to family assessment and intervention (3th ed.). Davis.

Yeh, C-H., Lee, T-T., Chen, M-L., \& Li, W. (2000). Adaptational process of parent of pediatric oncology patients. Pediatr Hematol Oncol, 17(2): 119-131. https://doi.org/10.1080/088800100276479

Yıldırım, A., \& Şimşek, H.(2011). Sosyal bilimlerde nitel araştırma yöntemleri (8. Baskı). Seçkin Yayınları.

Zengin, O., Selçuk, S., Duysak, Y., Soytürk, G., Orbays, E., \& Tekin, O. (2012). Kanserli çocuğa sahip ailelerin aşama yaklaşımına göre gösterdikleri tepkiler. J DU Health Sci Inst., 2(1): 1-4. ISSN: 2146-443X2146-443X

Correspondence

Dr. Feyruz Usluoğlu feyruzusluoglu@gmail.com 